\title{
ECOLOGY
}

\section{Spider assemblage (Arachnida: Araneae) associated with canopies of Vochysia divergens (Vochysiaceae) in the northern region of the Brazilian Pantanal}

\author{
Leandro D. Battirola ${ }^{1 *}$, Daniel A. Batistella ${ }^{1}$, Germano H. Rosado-Neto ${ }^{2}$, \\ Antonio D. Brescovit ${ }^{3} \&$ Marinêz I. Marques ${ }^{4}$
}

\begin{abstract}
'Instituto de Ciências Naturais, Humanas e Sociais, Universidade Federal de Mato Grosso. Avenida Alexandre Ferronato 1200, Setor Industrial, 78557-267 Sinop, MT, Brazil.

${ }^{2}$ Departamento de Zoologia, Universidade Federal do Paraná. Caixa Postal 19020, 81531-980 Curitiba, PR, Brazil.

${ }^{3}$ Laboratório Especial de Coleções Zoológicas, Instituto Butantan. Avenida Vital Brasil 1500, Butantã,

05503-900 São Paulo, SP, Brazil.

${ }^{4}$ Instituto de Biociências, Universidade Federal de Mato Grosso. Avenida Fernando Corrêa da Costa 2367, Boa

Esperança, 78060-900 Cuiabá, MT, Brazil.

*Corresponding author. E-mail: Idbattirola@uol.com.br
\end{abstract}

\begin{abstract}
This study describes the composition and temporal variation of the spider assemblage (Arachnida: Araneae) associated with canopies of Vochysia divergens Pohl. (Vochysiaceae) in the northern region of the Brazilian Pantanal. Three $V$. divergens plants were sampled in 2004, at each seasonal period of the northern Pantanal (high water, receding water, dry season and rising water), using thermonebulization of the canopies with insecticide, totaling $396 \mathrm{~m}^{2}$ of sampled canopies. Analysis of abundance and richness of spider families were based on Non-Metric Multidimensional Scaling (NMDS) and Variance Analysis (ANOVA and MANOVA). A total of 7,193 spiders were collected (6,330 immatures; 88.0\%; 863 adults, $12.0 \%)$ distributed in 30 families. Araneidae (1,676 individuals), Anyphaenidae (1,631 individuals), Salticidae (1,542 individuals) and Pisauridae (906 individuals), were predominant, representing $80.0 \%$ of the sample. Ten different guilds were registered: aerial hunters, orb-weavers, nocturnal aerial runners and diurnal space web weavers dominated, sharing most ecological niches. The spider assemblage is affected by changes in the habitat structure, especially by the seasonal hydrological regime and variations in the phenology of $V$. divergens. The assemblage is composed of different groups of spiders. The dominant taxa and behavioral guilds differ in the different seasonal periods. Spiders were more abundant during the dry and rising water seasons, most likely reflecting a greater supply of potential prey, associated with new foliage and flowering at the canopy. The displacement of soil dwelling spiders to the trunks and canopies before and during the seasonal floods can change the structure and composition of the canopy assemblages. Oonopidae, Gnaphosidae and Caponiidae, were more frequent during the rising and high water seasons, which indicates that these taxa use the canopies of $V$. divergens as a refuge during the seasonal flooding in the Pantanal.
\end{abstract}

KEY WORDS. Invertebrates, diversity, forest canopy, seasonality, wetlands.

Arthropod communities associated with canopies of typical vegetation formations of the northern region of the Pantanal have been studied in recent years (e.g., MARQues et al. 2001, 2006, BatTirola et al. 2005, 2007, 2014). Spiders, considered the main predators of arthropods in most biomes (CARDOso et al. 2011), are mentioned in these studies as being important components of these communities, with specific assemblages on each host plant (SANTos et al. 2003, BatTirola et al. 2004, Marques et al. 2007, 2011).
The different composition of spider assemblages most likely reflects the complexity of habitats in the Pantanal. The geological and geomorphological history of this biome, together with its position on the banks of large phytogeographic domains (NuNES-DA-CUNHA \& JUNK 1999, 2014), associated with water seasonality (Junk et al. 1989), results in a variety of landscapes, vegetation types (including monodominant forests) and habitats with specific characteristics (Silva et al. 2000, NUNES-DA-CUNHA \& 
Junk 2011). The annual and multi-annual variations in the flood pulse affect the biota at different intensities and time scales (NUNES-DA-CUNHA \& JUNK 2004), causing terrestrial organisms to develop specific strategies to survive and adapt to the strong seasonality of this floodplain (ADIs et al. 2001, BATTIROLA et al. 2009).

Among the monodominant vegetation types in the northern region of the Pantanal of Mato Grosso, the "cambarazais" are outstanding (SILVA et al. 2000). These are seasonally flooded forests with dominance of Vochysia divergens Pohl. (Vochysiaceae) (ARIEIRA \& NunEs-DA-CUNHA 2006). Vochysia divergens is considered invasive to native pastures, posing a problem for the local people, who rely on native grasslands for livestock (Ротт \& Ротт 1994, NunEs-da-Cunha et al. 2000, Nunes-DA-Cunha \& Junk 2004). While $V$. divergens is characterized as a problem for landowners, it is ecologically important as a habitat and refuge for the wildlife (Pott \& Pott 1994, Fassnacht 1998, Marques et al. 2006), mainly when it is a fully grown tree (NUNES-DA-CUNHA \& JUNK 2014).

The distribution and species richness of predators like spiders may be influenced by the structural conditions of the host plants even though they do not generally have a direct relationship with these plants (Raizer \& Amaral 2001, Souza \& Martins 2004, 2005, SOUZA \& MódENA 2004), or by changes in environmental conditions (WOLDA 1988). Spiders depend on plant structures to attach their webs and to forage. Plant phenology (flowering, fruit development and leaf fall periods), the distribution of food resources such as the presence of potential prey, often represented by herbivorous insects associated with that host, are also important to these arachnids (Costello \& DAANE 1995, RinAldi \& Forti 1997, SCHAIK et al. 1993, ARANGO et al. 2000).

Considering the importance of conservation and management of the specific monodominant forests of $V$. divergens in the Pantanal, as well as the biological diversity associated with these habitats, this study analyzed the composition and temporal variation of the spider assemblage in $V$. divergens canopies. Our goal was to evaluate the use of this habitat by spiders over different seasonal periods, in the northern region of the Pantanal of Mato Grosso, Brazil.

\section{MATERIAL AND METHODS}

The study area is located at the Retiro Novo Farm, Nossa Senhora do Livramento, Mato Grosso, Brazil. This area is situated on the right bank of the Cuiabá River and on the left bank of the Bento Gomes River, Pantanal of Poconé $\left(16^{\circ} 15^{\prime} 24^{\prime \prime}-17^{\circ} 54^{\prime} 32^{\prime \prime} \mathrm{S}\right.$, $\left.56^{\circ} 36^{\prime} 24^{\prime \prime}-57^{\circ} 56^{\prime} 23^{\prime \prime} \mathrm{W}\right)\left(16^{\circ} 15^{\prime} 12^{\prime \prime} \mathrm{S}, 56^{\circ} 22^{\prime} 12^{\prime \prime} \mathrm{W}\right)$. We studied spiders in a monodominant forest of $V$. divergens, known as "cambará" whose association is denominated "cambarazal" (NASCIMENTO \& NUNES-DA-CUNHA 1989). The study area is subjected to a rainy season from October to April and to annual flooding of 0.6-1.5 m height, generally between December and March, with four seasonal periods defined as high water (January-March), receding water (April-June), dry season (July-September), and rising water (October-December) (Heckman 1998). Data on the phenology of $V$. divergens correspond to those presented by Nunes-DA-CunHA et al. (2000) e NunEs-dA-CunHA \& JunK (2004).

Twelve specimens of $V$. divergens were nebulized using thermonebulization of the canopies, three individuals in each seasonal period (high water, receding water, dry season and rising water in 2004). The sampled trees were selected according to the criteria proposed by ADIs et al. (1998), and the methodological procedures according to BatTirola et al. (2004). The entire diameter at the base of these trees was surrounded by nylon funnels ( $1 \mathrm{~m}$ in diameter each), distributed according to the shape and architecture of the canopy, bringing to a total of $396 \mathrm{~m}^{2}$ of assessed canopies $\left(33 \mathrm{~m}^{2}\right.$ per tree sampled). These collector funnels had a plastic collection bottle (1 L) at their base with $92 \%$ ethanol and were suspended at about $1 \mathrm{~m}$ from the ground by strings tied to surrounding trees. During the high water period the funnels were suspended at 2.5 $\mathrm{m}$ above the ground due to flooding of the forest (water depth ranging from 0.9 to $1.25 \mathrm{~m}$ ). The nebulization was applied for 10 minutes using a Swingfog SN50 thermonebulizator, employing the non-residual synthetic pyrethroid (Lambdacialotrina at $0.5 \%$ - Icon ${ }^{\circledR}$ ), diluted in diesel oil at a concentration of $1 \%$, associated with the synergistic (DDVP 0.1\%). This nebulization was performed at around 6:00 am, during less intense air circulation, which allows the cloud of insecticide to slowly rise through the canopy, without dispersion (ADIs et al. 1998).

The collected material was transported to the Laboratório de Ecologia e Taxonomia de Artrópodes (LETA) at the Instituto de Biociências, Universidade Federal de Mato Grosso in Cuiabá, MT, and subsequently forwarded for identification to the Laboratório Especial de Coleções Zoológicas, Instituto Butantan, São Paulo, SP, where it is deposited. The behavioral guilds were determined according to HÖFER \& BRESCOVIT (2001) and DiAs et al. (2010).

Data from the spider assemblage were analyzed using the ordination method by Non-Metric Multidimensional Scaling (NMDS) for the abundance and presence-absence (qualitative) of families (adults + immatures), in order to reduce the dimensionality of information from multiple taxa (CLARKE 1993). The dissimilarity between the sampling units was calculated using the associative matrix by means of the Bray-Curtis and Sørensen Index. Multivariate Analysis of Variance (MANOVA) was employed using the scores of NMDS dimensions with data of abundance and presence-absence, and Analysis of Variance (ANOVA) using a NMDS axes for presence-absence, associated with the $a$ posteriori Tukey test. These analyses test the existence of average differences in the composition of the spider assemblage using categorical variables (high water, receding water, dry season and rising water). They were carried out using the free software R 2.12.1 (R CORE Team 2013), Vegan package (OKsanen et al. 2014).

\section{RESULTS}

In $396 \mathrm{~m}^{2}$ of $V$. divergens canopies, 7,193 spiders from 30 families were sampled $\left(18.2 \mathrm{ind} . / \mathrm{m}^{2}\right)$. Of this total, 6,330 individuals are immatures $\left(88.0 \%, 16.0 \mathrm{ind} . / \mathrm{m}^{2}\right)$ and 863 adults $(12.0 \%$, 
2.2 ind. $\left./ \mathrm{m}^{2}\right)$. Araneidae (1,676 ind., 4.2 ind. $\left./ \mathrm{m}^{2}\right)$, Anyphaenidae (1,631 ind., 4.1 ind. $\left./ \mathrm{m}^{2}\right)$, Salticidae (1,542 ind., 3.9 ind. $\left./ \mathrm{m}^{2}\right)$ and Pisauridae (906 ind., 2.3 ind. $/ \mathrm{m}^{2}$ ) were the most abundant families, representing $80 \%$ of the sample (Tables 1 and 2). Amaurobiidae, Ctenidae, Mimetidae, Prodidomidae, Sparassidae and Trechaleidae present only immature individuals (Table 1).

Within the seasonal periods, receding water (2,398 ind., $33.3 \%, 24.2$ ind. $\left./ \mathrm{m}^{2}\right)$ and dry season (2,101 ind., $29.2 \%, 21.2$ ind. $/ \mathrm{m}^{2}$ ) were the periods with most abundant assemblages of spiders, followed by rising water (1,663 ind., 23.1\%, 16.8 ind./ $\mathrm{m}^{2}$ ) and high water (1,031 ind., $14.3 \%, 10.4$ ind. $/ \mathrm{m}^{2}$ ) (Table 2, Fig. 1). The coefficient of variance for the abundance of the family Araneae was $89.1 \%$ captured by ordering with two dimensions (stress 0.09), indicating that the assemblages in $V$. divergens canopies vary significantly throughout the seasonal periods (MANOVA: Pillai Trace $=1.27, \mathrm{~F}_{3,8}=4.67, \mathrm{p}<0.01$ ) (Fig. 2).
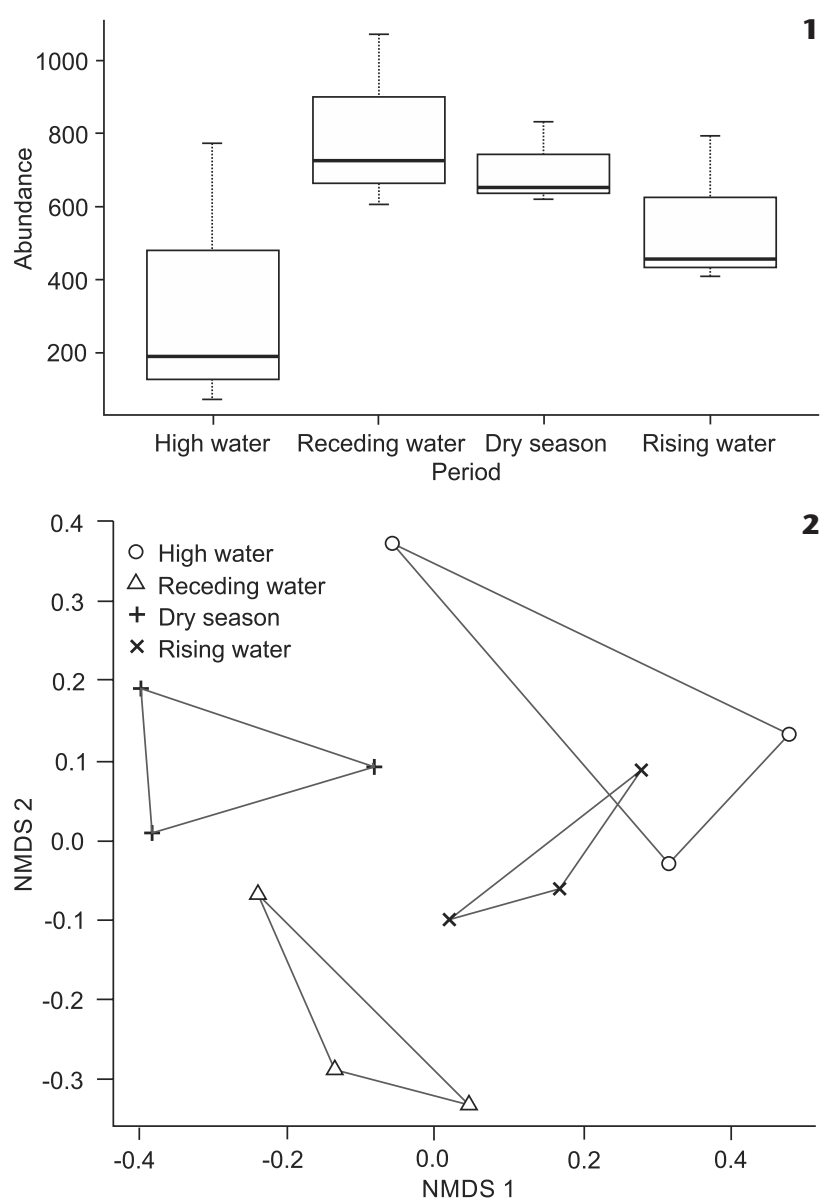

Figures 1-2. (1) Abundance of spiders and (2) ordination of assemblages of spiders in canopies of Vochysia divergens throughout the different seasonal periods in the northern region of the Pantanal of Mato Grosso, Brazil, based on a Bray-Curtis dissimilarity matrix (two axes, stress $=0.09$ ).
Table 1. Total abundance (number of individuals) of males, females and immatures of spiders sampled throughout the different seasonal periods in canopies of Vochysia divergens in the northern region of the Pantanal of Mato Grosso, Brazil.

\begin{tabular}{|c|c|c|c|}
\hline \multirow{2}{*}{ Families } & \multicolumn{2}{|c|}{ Adults } & \multirow{2}{*}{ Immatures } \\
\hline & Males & Females & \\
\hline Araneidae & 41 & 87 & 1,548 \\
\hline Anyphaenidae & 61 & 75 & 1,495 \\
\hline Salticidae & 107 & 142 & 1,293 \\
\hline Pisauridae & - & - & 906 \\
\hline Dictynidae & 30 & 67 & 161 \\
\hline Theridiidae & 9 & 14 & 241 \\
\hline Thomisidae & 30 & 10 & 186 \\
\hline Oonopidae & 60 & 39 & 23 \\
\hline Corinnidae & 14 & 12 & 76 \\
\hline Gallieniellidae & 6 & 10 & 79 \\
\hline Gnaphosidae & 8 & - & 50 \\
\hline Titanoecidae & 1 & 3 & 43 \\
\hline Sparassidae & - & - & 37 \\
\hline Oxyopidae & 1 & - & 27 \\
\hline Linyphiidae & 5 & 5 & 15 \\
\hline Philodromidae & 9 & 4 & 6 \\
\hline Mimetidae & - & - & 14 \\
\hline Hersiliidae & 2 & - & 6 \\
\hline Tetragnathidae & 3 & - & 4 \\
\hline Selenopidae & - & 1 & 3 \\
\hline Trechaleidae & - & - & 4 \\
\hline Caponiidae & - & 1 & 2 \\
\hline Ctenidae & - & - & 2 \\
\hline Pholcidae & - & 1 & 1 \\
\hline Prodidomidae & - & - & 2 \\
\hline Senoculidae & 1 & - & 1 \\
\hline Theridiosomatidae & 1 & - & 1 \\
\hline Amaurobiidae & - & - & 1 \\
\hline Mysmenidae & 1 & - & - \\
\hline Uloboridae & 1 & - & - \\
\hline Indeterminated families & - & - & 84 \\
\hline Total & 391 & 472 & 6,330 \\
\hline
\end{tabular}

Little variation was observed in the dominant groups in each seasonal period evaluated. Araneidae, Anyphaenidae, Salticidae and Pisauridae predominated in all periods evaluated, accompanied by Theridiidae (high water), Dictynidae (receding water and dry season), and Thomisidae (rising water). Individuals of some families were recorded exclusively in only one of the seasonal periods. Selenopidae and Caponiidae were sampled only during the high water season, and Prodidomidae in the rising water. During receding water, a period with the highest abundance of spiders in $V$. divergens canopies, the unique occurrence of Amaurobiidae, Ctenidae, Mysmenidae, Senoculidae, Theridiosomatidae, Trechaleidae and Uloboridae was observed (Table 2). The presence-absence data for families per season, show that the coefficient of variance captured by ordering with a NMDS axis was $61.2 \%$ (stress 0.27 ), indicating that the number of families varied significantly between seasons (ANOVA: $\mathrm{F}_{3.8}=8.29, \mathrm{p}<0.01$ ); differences were significant both 
for rising and high water (Tukey, $\mathrm{p}=0.02)$, rising and receding water (Tukey, $\mathrm{p}=0.02$ ), respectively (Fig. 3 ).

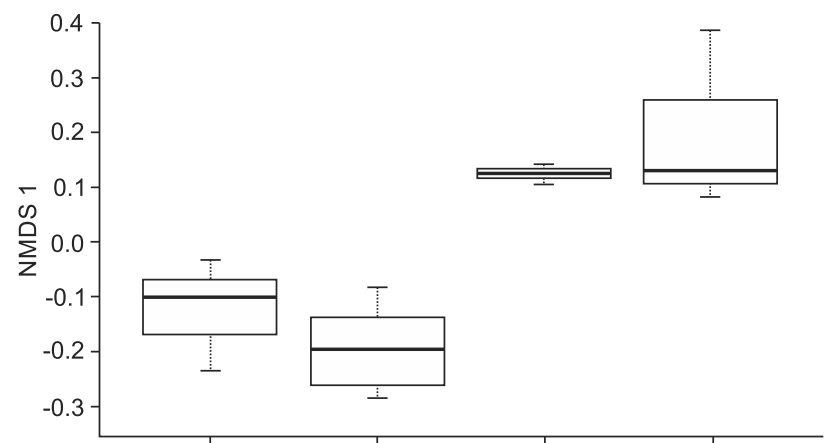

High water Receding water Dry season Rising water Period

Figure 3. Variation in the number of spider families based on the Sorensen index in canopies of Vochysia divergens throughout the different seasonal periods in the northern region of the Pantanal of Mato Grosso, Brazil.

Ten behavioral guilds were found in $V$. divergens canopies (Table 2). Aerial hunters (1,761 ind.), orb weavers (1,687 ind.), nocturnal aerial runners (1,651 ind.) and diurnal space web weavers (1,475 ind.) predominated. Both diurnal and nocturnal aerial ambushers were represented with only 245 and 60 individuals, respectively. The guilds varied in relation to seasonal periods (ANOVA: $\mathrm{F}_{9.30}=9.17, \mathrm{p}<0.01$ ). Orb weavers and aerial hunters predominated over all periods, accompanied by diurnal space web weavers and nocturnal aerial runners.

A considerably differentiated pattern was observed for the clusters of soil dwelling spiders that were represented by nocturnal ground runners (122 ind.), ground runners (60 ind.), ground weavers (47 ind.) and nocturnal ground hunters (3 ind.). Ground runners (Gnaphosidae and Prodidomidae) and nocturnal ground runners (Oonopidae) were more frequent during the rising water season. Caponiidae (nocturnal ground hunters) were only sampled during the high water, while Titanoecidae (ground weavers), although they occurred during rising water and in high water season, were more abundant in the dry period (Table 2).

\section{DISCUSSION}

Variation was observed in the composition and structure of the spider assemblage in the canopies of $V$. divergens, with spiders groups varying throughout the seasonal periods, with significant abundance during periods of receding water and dry season, as well as the restricted occurrence of taxa in some periods. Many of these variations can be associated with habitat conditions, considering that the habitat structure is a fundamental requisite for the organization of spider assemblages (CARDoso et al. 2011).
In canopies of $V$. divergens, the phenology of the plant and the hydrological seasonality of the Pantanal are the two main factors in the structuring of this habitat. Due to the pronounced water seasonality in the Pantanal ecosystem, many species have developed morphological, physiological and phenological adaptations, e.g. synchronizing their stages of development to the specific seasonal periods of the region. The phenology of $V$. divergens is associated with seasonal flooding with renewal of foliage and flowering occurring during the receding water and dry season, respectively (NUNES-DA-CUNHA \& JUNK 2004). These periods correspond to those with more frequent occurrence of spiders associated with their canopies. This fluctuation probably reflects the greater supply of potential prey, caused by changes in canopy structure, e.g., the advent of new foliage and flowering which increase the availability of resources for herbivorous species that may be potential prey for spiders (e.g., MARQUEs et al. 2006). The change in the canopy structure of $V$. divergens expands the area that can be used by spiders (immatures and adults) for fixing their webs, as well as foraging and refuge areas, mainly for immatures, representing the majority of the assemblage.

The spider assemblage in $V$. divergens canopies is indirectly influenced by water seasonality: 1) by its direct influence on the phenology of the host plants and 2) by inciting the displacement of soil organisms to the trunks and canopies before and during the seasonal floods. The seasonal fluctuation of taxa such as Oonopidae, Gnaphosidae and Caponiidae in V. divergens canopies shows this behavior, indicating that soil spiders move to higher layers of the habitats such as trunks and canopies, to survive during the flood periods, which was observed in ants and millipedes in the same region (Adis et al. 2001, BATTIRola et al. 2009).

Similarly, AdIs $(1981,1992)$ sustained that migration from the ground to the forest canopy in the Central Amazon begins during the rising water period, already ten to eight weeks prior to forest inundation. BatTirola et al. (2010) reported, for the same forest in the Pantanal, that activity density of ground dwelling spiders is higher in periods of rising water and high water than in the other periods, especially for Oonopidae and Gnaphosidae. The greater movement of spiders coincides with the flooding, which forces these arachnids and other invertebrates to move continuously, seeking refuge, in a similar manner as recorded at the Central Amazon (ADIs 1981, 1997).

The dominance of four spider families in $V$. divergens canopies is most likely due to niche sharing and the smaller niche overlap of these spiders, since they represent a distinct behavioral guild. Differences between the dimensions of the ecological niches may reduce competition and facilitate the coexistence of species (Schoener 1974, Gilbert et al. 2008). Araneidae (orb weavers) and Pisauridae (diurnal space web weavers) represented the weavers and Anyphaenidae (aerial hunters) and Salticidae (nocturnal aerial runners) the hunters. The most important prey for spiders are arthropods. However, competition may be reduced by adopting diverse foraging methods, such as type of prey, circadian rhythm (day and night), vertical stratification 
Table 2. Abundance (number of individuals), mean \pm standard deviation of abundance, frequency (\%) and behavioral guilds of spiders sampled in canopies of Vochysia divergens throughout the different seasonal periods in the northern region of the Pantanal of Mato Grosso, Brazil. (AH) Aerial hunters, (DAA) diurnal aerial ambushers, (DSWW) diurnal space web weavers, (GR) ground runners, (GW) ground weavers, (NAA) nocturnal aerial ambushers, (NAR) nocturnal aerial runners, (NGH) nocturnal hunters ground, (NGR) nocturnal ground runners, $(\mathrm{OW})$ orb weavers.

\begin{tabular}{|c|c|c|c|c|c|c|c|c|}
\hline \multirow{2}{*}{ Taxa } & \multicolumn{4}{|c|}{ Seasonal periods } & \multirow{2}{*}{ Total } & \multirow{2}{*}{ Mean \pm SD } & \multirow{2}{*}{ Frequency (\%) } & \multirow{2}{*}{ Behavioral guild } \\
\hline & High water & Receding water & Dry season & Rising water & & & & \\
\hline \multicolumn{9}{|l|}{ Amaurobiidae } \\
\hline Amaurobiidae indeterminated & - & 1 & - & - & 1 & $0.2 \pm 0.5$ & 25 & NAA \\
\hline \multicolumn{9}{|l|}{ Anyphaenidae } \\
\hline Jessica erythrostoma (Mello-Leitão, 1939) & - & 4 & - & & 4 & $1.0 \pm 2.1$ & 25 & $\mathrm{AH}$ \\
\hline Jessica sp. & - & 7 & - & - & 7 & $1.7 \pm 3.7$ & 25 & $\mathrm{AH}$ \\
\hline Teudis sp. & - & 2 & - & - & 2 & $0.5 \pm 1.1$ & 25 & $\mathrm{AH}$ \\
\hline Anyphaenidae sp. 1 & 12 & 5 & - & 2 & 19 & $4.7 \pm 10.1$ & 75 & $\mathrm{AH}$ \\
\hline Anyphaenidae sp. 2 & 7 & 2 & - & 1 & 10 & $2.5 \pm 5.3$ & 75 & $\mathrm{AH}$ \\
\hline Anyphaenidae indeterminated & 179 & 299 & 596 & 515 & 1,589 & $397.2 \pm 842.7$ & 100 & $\mathrm{AH}$ \\
\hline Total Anyphaenidae & 198 & 319 & 596 & 518 & 1,631 & $407.7 \pm 864.9$ & 100 & $\mathrm{AH}$ \\
\hline \multicolumn{9}{|l|}{ Araneidae } \\
\hline Alpaida bicornuta (Taczanowski, 1878) & - & 5 & - & - & 5 & $1.2 \pm 2.6$ & 25 & OW \\
\hline Alpaida sp. & - & 1 & - & - & 1 & $0.2 \pm 0.5$ & 25 & OW \\
\hline Araneus sp. & - & 2 & - & - & 2 & $0.5 \pm 1.1$ & 25 & OW \\
\hline Cyclosa sp. & - & 1 & - & - & 1 & $0.2 \pm 0.5$ & 25 & OW \\
\hline Eustala sp. & - & 7 & - & - & 7 & $1.7 \pm 3.7$ & 25 & OW \\
\hline Hypognatha sp. & - & 1 & - & - & 1 & $0.2 \pm 0.5$ & 25 & OW \\
\hline Manogea sp. & - & 1 & - & - & 1 & $0.2 \pm 0.5$ & 25 & OW \\
\hline Metazygia gregalis (O.P. Cambridge, 1889) & - & 2 & - & - & 2 & $0.5 \pm 1.1$ & 25 & OW \\
\hline Metazygia sp. & - & 7 & - & - & 7 & $1.7 \pm 3.7$ & 25 & OW \\
\hline Araneidae sp. 1 & 9 & 25 & - & 4 & 38 & $9.5 \pm 20.1$ & 75 & OW \\
\hline Araneidae sp. 2 & 3 & 4 & - & 1 & 8 & $2.0 \pm 4.2$ & 75 & OW \\
\hline Araneidae sp. 3 & - & 1 & - & - & 1 & $0.2 \pm 0.5$ & 25 & OW \\
\hline Araneidae indeterminated & 256 & 710 & 263 & 373 & 1,602 & $400.5 \pm 849.6$ & 100 & OW \\
\hline Total Araneidae & 268 & 767 & 263 & 378 & 1,676 & $419.0 \pm 888.8$ & 100 & OW \\
\hline \multicolumn{9}{|l|}{ Caponiidae } \\
\hline Caponiidae Indeterminated & 3 & - & - & - & 3 & $0.7 \pm 1.6$ & 25 & $\mathrm{NGH}$ \\
\hline \multicolumn{9}{|l|}{ Corinnidae } \\
\hline Castianeira sp. & - & 1 & - & - & 1 & $0.2 \pm 0.5$ & 25 & $\mathrm{AH}$ \\
\hline Corinnidae indeterminated & 48 & 26 & 15 & 12 & 101 & $25.2 \pm 54.1$ & 100 & $\mathrm{AH}$ \\
\hline Total Corinnidae & 48 & 27 & 15 & 12 & 102 & $25.5 \pm 54.1$ & 100 & $\mathrm{AH}$ \\
\hline \multicolumn{9}{|l|}{ Ctenidae } \\
\hline Ctenidae indeterminated & - & 2 & - & - & 2 & $0.5 \pm 1.1$ & 25 & NAA \\
\hline \multicolumn{9}{|l|}{ Dictynidae } \\
\hline Dictyna sp. & - & 12 & - & - & 12 & $3.0 \pm 6.4$ & 25 & DSWW \\
\hline Dictynidae sp. 1 & - & - & - & 1 & 1 & $0.2 \pm 0.5$ & 25 & DSWW \\
\hline Dictynidae sp. 2 & - & - & - & 1 & 1 & $0.2 \pm 0.5$ & 25 & DSWW \\
\hline Dictynidae indeterminated & 15 & 89 & 123 & 37 & 264 & $66.0 \pm 140.0$ & 100 & DSWW \\
\hline Total Dictynidae & 15 & 101 & 123 & 39 & 278 & $69.5 \pm 147.4$ & 100 & DSWW \\
\hline \multicolumn{9}{|l|}{ Gallieniellidae } \\
\hline Galianoella leucostigma (Mello-Leitão, 1941) & 9 & 2 & - & 5 & 16 & $4.0 \pm 8.5$ & 75 & NAR \\
\hline Gallieniellidae indeterminated & 16 & 22 & 38 & 3 & 79 & $19.7 \pm 41.9$ & 100 & NAR \\
\hline Total Gallieniellidae & 25 & 24 & 38 & 8 & 95 & $23.7 \pm 50.4$ & 100 & NAR \\
\hline \multicolumn{9}{|l|}{ Gnaphosidae } \\
\hline Gnaphosidae Indeterminated & 0 & 6 & 23 & 29 & 58 & $14.5 \pm 30.7$ & 75 & GR \\
\hline \multicolumn{9}{|l|}{ Hersiliidae } \\
\hline Hersiliidae indeterminated & 3 & 3 & - & 2 & 8 & $2.0 \pm 4.2$ & 75 & NAA \\
\hline Linyphiidae & & & & & & & & \\
\hline Sphecozone sp. & - & 2 & - & - & 2 & $0.5 \pm 1.1$ & 25 & DSWW \\
\hline Linyphiidae indeterminated & 17 & 5 & - & 1 & 23 & $5.7 \pm 12.2$ & 75 & DSWW \\
\hline Total Linyphiidae & 17 & 7 & - & 1 & 25 & $6.2 \pm 13.2$ & 75 & DSWW \\
\hline Mimetidae & & & & & & & & \\
\hline Mimetidae indeterminated & - & 1 & 9 & 4 & 14 & $3.5 \pm 7.4$ & 75 & NAR \\
\hline Mysmenidae & & & & & & & & \\
\hline Mysmenidae indeterminated & - & 1 & - & - & 1 & $0.2 \pm 0.5$ & 25 & OW \\
\hline & & & & & & & & Continues \\
\hline
\end{tabular}


Table 2. Continued.

\begin{tabular}{|c|c|c|c|c|c|c|c|c|}
\hline \multirow{2}{*}{ Taxa } & \multicolumn{4}{|c|}{ Seasonal periods } & \multirow{2}{*}{ Total } & \multirow{2}{*}{ Mean \pm SD } & \multirow{2}{*}{ Frequency (\%) } & \multirow{2}{*}{ Behavioral guilc } \\
\hline & High water & Receding water & Dry season & Rising water & & & & \\
\hline \multicolumn{9}{|l|}{ Oonopidae } \\
\hline Gamasomorphinae sp. & - & 6 & - & - & 6 & $1.5 \pm 3.2$ & 25 & NGR \\
\hline Oonopidae sp. 1 & - & - & - & 1 & 1 & $0.2 \pm 0.5$ & 25 & NGR \\
\hline Oonopidae sp. 2 & - & - & - & 2 & 2 & $0.5 \pm 1.1$ & 25 & NGR \\
\hline Oonopidae indeterminated & 20 & 14 & 8 & 71 & 113 & $28.2 \pm 59.9$ & 100 & NGR \\
\hline Total Oonopidae & 20 & 20 & 8 & 74 & 122 & $30.5 \pm 64.7$ & 100 & NGR \\
\hline \multicolumn{9}{|l|}{ Oxyopidae } \\
\hline Oxyopidae indeterminated & 16 & 5 & 5 & 2 & 28 & $7.0 \pm 14.8$ & 100 & $\mathrm{AH}$ \\
\hline \multicolumn{9}{|l|}{ Philodromidae } \\
\hline Gephyrellula sp. & - & - & - & 2 & 2 & $0.5 \pm 1.1$ & 25 & DAA \\
\hline Philodromidae indeterminated & - & - & 10 & 7 & 17 & $4.2 \pm 9.0$ & 50 & DAA \\
\hline Total Philodromidae & - & - & 10 & 9 & 19 & $4.7 \pm 10.1$ & 50 & DAA \\
\hline \multicolumn{9}{|l|}{ Pholcidae } \\
\hline Pholcidae indeterminated & 1 & - & - & 1 & 2 & $0.5 \pm 1.1$ & 25 & DSWW \\
\hline \multicolumn{9}{|l|}{ Prodidomidae } \\
\hline Prodidomidae indeterminated & - & - & - & 2 & 2 & $0.5 \pm 1.1$ & 25 & GR \\
\hline \multicolumn{9}{|l|}{ Pisauridae } \\
\hline Pisauridae indeterminated & 102 & 477 & 277 & 50 & 906 & $226.5 \pm 480.5$ & 100 & DSWW \\
\hline \multicolumn{9}{|l|}{ Salticidae } \\
\hline Bellota sp. & - & 1 & - & - & 1 & $0.2 \pm 0.5$ & 25 & NAR \\
\hline Helvetia sp. & - & 1 & - & - & 1 & $0.2 \pm 0.5$ & 25 & NAR \\
\hline Salticidae sp. 1 & 7 & 14 & 29 & 11 & 61 & $15.2 \pm 32.3$ & 100 & NAR \\
\hline Salticidae sp. 2 & 2 & 8 & 7 & 5 & 22 & $5.5 \pm 11.7$ & 100 & NAR \\
\hline Salticidae sp. 3 & 1 & - & - & - & 1 & $0.2 \pm 0.5$ & 25 & NAR \\
\hline Salticidae Indeterminated & 169 & 400 & 554 & 333 & 1,456 & $364.0 \pm 772.2$ & 100 & NAR \\
\hline Total Salticidae & 179 & 424 & 590 & 349 & 1,542 & $385.5 \pm 817.7$ & 100 & NAR \\
\hline Selenopidae & & & & & & & & \\
\hline Selenopidae indeterminated & 4 & - & - & - & 4 & $1.0 \pm 2.1$ & 25 & NAA \\
\hline Senoculidae & & & & & & & & NAA \\
\hline Senoculus sp. & - & 1 & - & - & 1 & $0.2 \pm 0.5$ & 25 & NAA \\
\hline Senoculidae indeterminated & - & 1 & - & - & 1 & $0.2 \pm 0.5$ & 25 & NAA \\
\hline Total Senoculidae & - & 2 & - & - & 2 & $0.5 \pm 1.1$ & 25 & NAA \\
\hline Sparassidae & & & & & & & & \\
\hline Sparassidae indeterminated & 2 & 18 & 3 & 14 & 37 & $9.2 \pm 19.6$ & 100 & NAA \\
\hline Tetragnathidae & & & & & & & & \\
\hline Tetragnathidae indeterminated & 1 & 5 & 1 & - & 7 & $1.7 \pm 3.7$ & 75 & OW \\
\hline Theridiidae & & & & & & & & \\
\hline Anelosimus sp. & - & 1 & - & - & 1 & $0.2 \pm 0.5$ & 25 & DSWW \\
\hline Argyrodes sp. & - & 2 & - & - & 2 & $0.5 \pm 1.1$ & 25 & DSWW \\
\hline Theridion sp. & - & 1 & - & - & 1 & $0.2 \pm 0.5$ & 25 & DSWW \\
\hline Theridiidae sp. 1 & 2 & 1 & - & - & 3 & $0.7 \pm 1.6$ & 50 & DSWW \\
\hline Theridiidae sp. 2 & 1 & 1 & - & - & 2 & $0.5 \pm 1.1$ & 50 & DSWW \\
\hline Theridiidae indeterminated & 91 & 91 & 24 & 49 & 255 & $63.7 \pm 135.2$ & 100 & DSWW \\
\hline Total Theridiidae & 94 & 97 & 24 & 49 & 264 & $66.0 \pm 140.0$ & 100 & DSWW \\
\hline Theridiosomatidae & & & & & & & & \\
\hline Theridiosomatidae indeterminat & & & & & & & & \\
\hline Thomisidae & - & 2 & - & - & 2 & $0.5 \pm 1.1$ & 25 & OW \\
\hline Tmarus sp. & - & 1 & - & - & 1 & $0.2 \pm 0.5$ & 25 & DAA \\
\hline Tobias sp. & - & 3 & - & - & 3 & $0.7 \pm 1.6$ & 25 & DAA \\
\hline Thomisidae sp. 1 & - & - & 1 & - & 1 & $0.2 \pm 0.5$ & 25 & DAA \\
\hline Thomisidae sp. 2 & - & - & 1 & - & 1 & $0.2 \pm 0.5$ & 25 & DAA \\
\hline Thomisidae indeterminated & 20 & 34 & 82 & 84 & 220 & $55.0 \pm 116.7$ & 100 & DAA \\
\hline Total Thomisidae & 20 & 38 & 84 & 84 & 226 & $56.5 \pm 119.8$ & 100 & DAA \\
\hline Titanoecidae & & & & & & & & \\
\hline Titanoecidae indeterminated & 1 & - & 32 & 14 & 47 & $11.7 \pm 24.9$ & 75 & GW \\
\hline Trechaleidae & & & & & & & & \\
\hline Trechaleidae indeterminated & - & 4 & - & - & 4 & $1.0 \pm 2.1$ & 25 & NAA \\
\hline Uloboridae & & & & & & & & \\
\hline Uloboridae indeterminated & - & 1 & - & - & 1 & $0.2 \pm 0.5$ & 25 & ow \\
\hline Indeterminated Families & 14 & 46 & - & 24 & 84 & & & \\
\hline Total & 1,031 & 2,398 & 2,101 & 1,663 & 7,193 & & & \\
\hline
\end{tabular}


(soil and canopy), and also as a result of the size of body and phenology of species (CARDoso et al. 2011). The use of different strategies to obtain resources reduces the competition between species, and allows their coexistence (Moran \& SouTHwood 1982, Pianka 1994, Blondel 2003, Wilson 1999).

The assemblages of spiders in habitats with similar structures may be composed of different species, but have similar guild composition (CARDOso et al. 2011). This was verified in studies of spider assemblages in canopies in areas of monodominant vegetation in the northern region of the Pantanal of Mato Grosso (SAntos et al. 2003, BatTiRola et al. 2004, Castilho et al. 2005, Marques et al. 2007). Similar dominant groups to those found in $V$. divergens canopies (e.g., Salticidae, Anyphaenidae, Araneidae, Corinnidae and Pisauridae), were obtained in the canopies of Calophyllum brasiliense Cambess (Gutiferae) (Marques et al. 2007). In the canopies of Attalea phalerata Mart. (Arecaceae), Salticidae, Araneidae, Oonopidae, Ctenidae and Dictynidae predominated when the water level was high (BATTirola et al. 2004), and Salticidae, Gnaphosidae, Araneidae and Oonopidae during the dry season (SANTOS et al. 2003). Anyphaenidae and Pisauridae, which are typical of $V$. divergens canopies, occurred with low density on $A$. phalerata. One of the factors that may contribute to the different assemblages on these two host plants is the different architecture of their canopies (e.g., Farrel \& Erwin 1988), which influences the presence of important microhabitats (BATTIRoLA et al. 2007, MARQues et al. 2009), e.g., sites for foraging and fixing webs, presence of prey and microclimate.

The assemblage of spiders associated with $V$. divergens canopies is seasonally affected by variations in habitat structure, especially by the hydrological regime and by the phenology of their host plant, and it is composed of different groups of spiders with a clear distinction between behavioral guilds. Due to the flooding of the forest, the canopies are regarded as a refuge for soil dwelling spiders during rising water and high water periods.

\section{ACKNOWLEDGEMENTS}

We dedicate this work to Prof. Joachim Adis (in memoriam) for his extensive studies of arthropods in the floodplains of the Pantanal and for his important contribution to this study. This study is in part due to scientific collaboration between the Max-Planck Institute for Limnology, Plön, Germany and the Federal University of Mato Grosso, Cuiabá, Brazil. We thank the Post-Graduate Program in Biological Sciences (Entomology), Federal University of Paraná, and the Post-Graduate Program in Ecology and Biodiversity Conservation, Institute of Biosciences UFMT for the infrastructure available for the development of this research and FAPEMAT (Fundação de Amparo à Pesquisa do Estado de Mato Grosso, Process 155864/2015). A.D. Brescovit is supported by a research grant 301776/2004-0 from CNPq.

\section{LITERATURE CITED}

ADIS J (1981) Comparative ecological studies of the terrestrial arthropod fauna in Central Amazonian inundation-forests. Amazoniana 7: 87-173.

ADIs J (1992) Überlebensstrategien terrestrischer Invertebraten in Überschwemmungswäldern Zentralamazoniens. Verhandlungen des Naturwissenschaftlicher Verein Hamburg (NF) 33: 21-114.

ADIs J (1997) Estratégias de sobrevivência de invertebrados terrestres em florestas inundáveis da Amazônia Central: Uma resposta à inundação de longo período. Acta Amazonica 27: 43-54. doi: 10.1590/1809-43921997271054

Adis J, Basset Y, Floren A, Hammond P, Linsenmair KE (1998) Canopy fogging of an overstory tree - recommendations for standardization. Ecotropica 4: 93-97. Available online at: http:// www.soctropecol.eu/ecotropica-1998 [Accessed: 28/07/2016]

Adis J, Marques MI, Wantzen KM (2001) First observations on the survival strategies of terricolous arthropods in the northern Pantanal wetland of Brazil. Andrias 15: 127-128.

Arango AM, Rico-Gray V, Parra-Tabla V (2000) Population structure, seasonality, and habitat use by the green lynx spider Peucetia viridans (Oxiopidae) inhabiting Cnidoscolus aconitifolius (Euphorbiaceae). Journal of Arachnology 28: 185-194. doi: 10.1636/0161-8202(2000)028[0185:PSSAHU]2.0.CO;2

ARIEIRA J, NunES-DA-CunHA C (2006) Fitossociologia de uma floresta inundável monodominante de Vochysia divergens Pohl (Vochysiaceae) no Pantanal Norte, MT, Brasil. Acta Botânica Brasilica 20: 568-580. doi: 10.1590/S0102-33062006000300007

Battirola LD, Marques Mi, Adis J, Brescovit AD (2004) Aspectos ecológicos da comunidade de Araneae (Arthropoda, Arachnida) em copas da palmeira Attalea phalerata Mart. (Arecaceae) no Pantanal de Poconé, Mato Grosso, Brasil. Revista Brasileira de Entomologia 48: 421-430. doi: 10.1590/S008556262004000300020

Battirola LD, Marques MI, Adis J, Delabie JHC (2005) Composição da comunidade de Formicidae (Insecta, Hymenoptera) em copas de Attalea phalerata Mart. (Arecaceae), no Pantanal de Poconé, Mato Grosso, Brasil. Revista Brasileira de Entomologia 49: 107-117. doi: 10.1590/S0085-56262005000100011

Battirola LD, Adis J, Marques MI, Silva FHO (2007) Comunidade de artrópodes associada à copa de Attalea phalerata Mart. (Arecaceae), durante o período de cheia no Pantanal de Poconé, Mato Grosso, Brasil. Neotropical Entomology 36: 640-651. doi: 10.1590/S1519-566X2007000500002

Battirola LD, Marques Mi, Rosado-Neto GH, Pinheiro TG, Pinho NGC (2009) Vertical and time distribution of Diplopoda (Arthropoda: Myriapoda) in a monodominant forest in Pantanal of Mato Grosso, Brazil. Zoologia 26: 479-487. doi: 10.1590/ S1984-46702009005000008

Battirola LD, Marques Mi, Brescovit AD, Rosado-Neto GH, Anjos KC (2010) Comunidade edáfica de Araneae (Arthropoda, Arachnida) em uma floresta sazonalmente inundável na região 
Norte do Pantanal de Mato Grosso, Brasil. Biota Neotropica 10: 173-183. doi: 10.1590/S1676-06032010000200022

Battirola LD, Santos GB, Rosado-Neto GH, Marques MI (2014) Coleoptera (Arthropoda, Insecta) associados às copas de Attalea phalerata Mart. (Arecaceae) no Pantanal de Poconé, Mato Grosso, Brasil. EntomoBrasilis 7: 20-28. doi: 10.12741/ ebrasilis.v7i1.316

Blondel J (2003) Guilds or functional groups: does it matter? Oikos 100: 223-231. doi: 10.1034/j.1600-0706.2003.12152.x

Cardoso P, Pekár S, Jocqué R, Coddington JA (2011) Global patterns of guild composition and functional diversity of spiders. PLoS ONE 6: e21710. doi: 10.1371/journal.pone.0021710

Castilho ACC, Marques MI, Adis J, Brescovit AD (2005) Distribuição sazonal e vertical de Araneae em área com predomínio de Attalea phalerata Mart. (Arecaceae), no Pantanal de Poconé, Mato Grosso, Brasil. Amazoniana 18: 215-239. Available online at: http://hdl.handle.net/11858/00-001M-0000-000F-D964-5 [Accessed: 31/07/2016]

Clarke KR (1993) Non-parametric multivariate analyses of changes in community structure. Australian Journal of Ecology 18: 117-143. doi: 10.1111/j.1442-9993.1993.tb00438.x

Costello MJ, DAANe KM (1995) Spider (Araneae) species composition and seasonal abundance in San Valley Grape Vineyards. Environmental Entomology 24: 823-831. doi: 10.1093/ee/24.4.823

Dias SC, Carvalho LS, Bonaldo AB, Brescovit AD (2010) Refining the establishment of guilds in Neotropical spiders (Arachnida: Araneae). Journal of Natural History 44: 219-239. doi: 10.1080/00222930903383503

Farrell BD, Erwin TL (1988) Leaf-Beetle community structure in an amazonian rainforest canopy, p. 73-90. In: Jolivet $P$, Petitpieree E, Hsiao TH (Eds.) Biology of Chrysomelidae. Dordrecht, Kluwer Academic Publishers, 615p

Fassnacht N (1998) Vochysia divergens Pohl. III - 4 Enzyklopadie der Holzgewachse 12: 1-4.

Heckman CW (1998) The Pantanal of Poconé. Biota and ecology in the northern section of the world's largest pristine wetland. Dordrecht, Kluwer Academic Publishers, 622p.

HöFER H, BRESCOvit AD (2001) Species and guild structure of a Neotropical spider assemblage (Araneae) from Reserva Ducke, Amazonas, Brazil. Andrias 15: 99-119.

Gilbert B, Srivastava DS, Kirby KR (2008) Niche partitioning at multiple scales facilitates coexistence among mosquito larvae. Oikos 117: 944-950. doi: 10.1111/j.0030-1299.2008.16300.x

Junk WJ, Bayley PB, Sparks RE (1989) The flood pulse concept in river-floodplain systems, p. 110-127. In: Dodge DP (Ed.) Proceedings of the International Large River Symposium (LARS). Ontario, Canadian Special Publication of Fisheries and Aquatic Sciences 106.

Marques Mi, Adis J, Nunes-da-Cunha C, Santos GB (2001) Arthropod biodiversity in the canopy of Vochysia divergens (Vochysiaceae), a forest dominant in the Brazilian Pantanal. Studies on Neotropical Fauna and Environment 36: 205210. doi: 10.1076/snfe.36.3.205.2122
Marques MI, Adis J, Santos GB, Battirola LD (2006) Terrestrial arthropods from tree canopies in the Pantanal of Mato Grosso, Brazil. Revista Brasileira de Entomologia 50: 257-267. doi: 10.1590/S0085-56262006000200007

Marques MI, Adis J, Battirola LD, Brescovit AD, Silva FHO, Silva JL (2007) Composição da comunidade de artrópodes associada à copa de Calophyllum brasiliense Cambess. (Guttiferae) no Pantanal mato-grossense, Mato Grosso, Brasil. Amazoniana 19: 131-148. Available online at: http://hdl.handle.net/11858/00-001M-0000-000F-D79D-A [Accessed: 31/07/2016]

Marques Mi, Santos GB, Battirola LD, Tissiani ASO (2009). Entomofauna associada à matéria orgânica em bainhas foliares de Attalea phalerata Mart. (Arecaceae), na região norte do Pantanal de Mato Grosso. Acta Biológica Paranaense 38: 93-112. doi: 10.5380/abpr.v38i0.16418

Marques Mi, Adis J, Battirola LD, Santos GB, Castilho ACC (2011) Arthropods associated with a forest of Attalea phalerata Mart. (Arecaceae) palm trees in the northern Pantanal of the Brazilian state of Mato Grosso, p. 431-468. In: Junk WJ, DA SILVA CJ, Nunes-Da-Cunha C, Wantzen KM (Eds.) The Pantanal of Mato Grosso: Ecology, biodiversity and sustainable management of a large Neotropical seasonal wetland. Sofia, Pensoft Publishers, 870p.

Moran VC, Southwood TRE (1982) The guild composition of arthropod communities in trees. Journal of Animal Ecology 51: 289-306. doi: 10.2307/4325

NAscimento MT, Nunes-DA-Cunha C (1989) Estrutura e composição florística de um cambarazal no Pantanal de Poconé, MT. Acta Botanica Brasílica 3: 3-23. doi: 10.1590/S010233061989000100001

Nunes-Da-Cunha C, Junk WJ (1999) Composição florística de capões e cordilheiras: localização das espécies lenhosas quanto ao gradiente de inundação no Pantanal de Poconé, MT, Brasil, p. 387-406. In: Anais do $2^{\circ}$ Simpósio sobre Recursos Naturais e Sócio-econômicos do Pantanal. Corumbá, EMBRAPA-Pantanal.

Nunes-DA-Cunha C, Junk WJ (2004) Year-to-year changes in water level drive the invasion of Vochysia divergens in Pantanal grasslands. Applied Vegetation Science 7: 103-110. doi: 10.1111/j.1654-109X.2004.tb00600.x

NunES-DA-CUNHA C, JUNK WJ (2011) A preliminary classification of habitats of the Pantanal of Mato Grosso and Mato Grosso do Sul, and its relation to national and international wetland classification systems, p. 127-141. In: JUNK WJ, DA-SILVA CJ, Nunes-da-Cunha C, Wantzen KM (Eds.) The Pantanal: Ecology, biodiversity and sustainable management of a large neotropical seasonal wetland. Sofia, Pensoft Publishers, 870p.

Nunes-dA-Cunha C, Junk WJ (2014) A classificação dos macrohabitats do Pantanal Mato-grossense, p. 77-122. In: Nunes-da-Cunha C, Piedade MTF, Junk WJ (Eds.) Classificação e delineamento das áreas úmidas brasileiras e de seus macrohabitats. Cuiabá, EdUFMT, 156p. 
Nunes-da-Cunha C, Junk WJ, Favalessa O, Costa CP, Almeida L (2000) Influences of dry and flooding periods on phenology and the dynamic of seedling and saplings of Vochysia divergens Pohl, in the Pantanal of Poconé, p. 871-874. In: German-Brazilian Workshop on Neotropical Ecosystems, Achievements and Prospects of Cooperative Research. Hamburg. Proceedings. Geesthacht: GKSS.

Oksanen J, Kindt R, Legendre P, O'Hara B, Stevens MHH, Oksanen MJ (2014) Suggests, M.A.S.S. 2014. VEGAN: Community Ecology Package, R package version 2.002. Available online at: http://CRAN.R-project.org/package=vegan [Accessed: $17 / 11 / 2014]$

Potт A, Poтt VJ (1994) Plantas do Pantanal. Brasília, Centro de Pesquisas Agropecuária do Pantanal, EMBRAPA-SPI, 320p.

PIANKA ER (1994) Evolutionary Ecology. New York, Harper Collins College Publishers, $5^{\text {th }}$ ed., 486 p.

RAizer J, Amaral MEC (2001) Does the structural complexity of aquatic macrophytes explain the diversity of associated spider assemblages? The Journal of Arachnology 29: 227-237. doi: 10.1636/0161-8202(2001)029[0227:DTSCOA]2.0.CO;2

R Core TeAm (2013) R: A language and environment for statistical computing. Vienna, R Foundation for Statistical Computing. Available online at: http://www.R-project.org [Accessed: 09/03/2015]

RINALDI IMP, FORTI LC (1997) Hunting spiders of woodland fragments and agricultural habitats in the Atlantic rain forest region of Brazil. Studies on Neotropical Fauna and Environment 32: 1-12. doi: 10.1080/01650521.1997.11432429

Santos GB, Marques MI, Adis J, DE Musis CR (2003) Artrópodos associados à copa de Attalea phalerata Mart. (Arecaceae), na região do Pantanal de Poconé, Mato Grosso, Brasil. Revista Brasileira de Entomologia 47: 211-224. doi: 10.1590/ S008556262003000200010

Schaik CP van, Terborgh JW, Wright SJ (1993) The phenology of tropical forests: Adaptive significance and consequences for primary consumers. Annual Review of Ecology and Systematics 24: 353-377.

SCHOENER TW (1974) Resource partitioning in ecological communities. Science 185: 27-39. doi: 10.1126/science.185.4145.27

Silva MP, Mauro R, Mourão G, Coutinho M (2000) Distribuição e quantificação de classes de vegetação do Pantanal através de levantamento aéreo. Revista Brasileira de Botânica 23: 143-152. doi: 10.1590/S0100-84042000000200004

Souza ALT, Martins RP (2004) Distribution of plant-dewelling spiders: Inflorescences versus vegetative branches. Austral Ecology 29: 342-349. doi: 10.1111/j.1442-9993.2004.01371.x

Souza ALT, Martins RP (2005) Foliage density of branches and distribution of plant-dwelling spiders. Biotropica 37: 416420. doi: 10.1111/j.1744-7429.2005.00055.x

Souza ALT, MóDena ES (2004) Distribution of spiders on different types of inflorescences in the Brazilian Pantanal. The Journal of Arachnology 32: 345-348. doi: 10.1636/M02-38

WILSON JB (1999) Guilds, functional types and ecological groups. Oikos 86: 507-522. doi: 10.2307/3546655

Wolda K (1988) Insect seasonality: why? Annual Review of Ecology and Systematics 19: 1-18.

Submitted: 17 October 2015

Received in revised form: 3 April 2016

Accepted: 8 May 2016

Editorial responsibility: Ricardo Pinto da Rocha

Author Contributions: LDB, GHRN and MIM designed the experiments; $L D B$ and MIM conducted the experiments; $L D B$, $D A B$ and $A D B$ analyzed the data; $L D B, D A B, G H R N, A D B$ and MIM wrote the paper.

Competing Interests: The authors have declared that no competing interests exist. 